\title{
A Study on Investor's Attitude towards Government Securities in Nepal
}

\author{
Pitambar Shrestha, MPhil \\ Faculty, KIST College \\ shresthapitambar@gmail.com
}

\begin{abstract}
The research paper sought to analyze the interest and awareness of Nepali people on government securities with one specific objectives of to examine the investor's interest and awareness towards government securities. The descriptive and analytical research design has been adopted in the study. The target population was the all investors of government securities in Nepal. The judgmental sampling method has been used to select the investor and 200 respondents were taken as its sample size. The data were collected using structured questionnaire. Chi-square test was done to examine the investor's interest and awareness towards government securities. It can be concluded that both educated and uneducated people are interested in government security. Thus, the research paper draws the conclusion that both poor and rich people are interested in government security'. The income is the major factor of investment on government security.
\end{abstract}

Key Words: Investment Decision, Government Securities, Investor, Attitude

\section{Introduction}

In Nepal, formal-financial system began in 1973 with the establishment of Nepal Bank Limited (NBL), which is the first commercial bank of country. The economic development of country depends upon the strategy implemented by the government and participation of private sectors. Nepal Rastra Bank (NRB) was established as central bank of Nepal under the Nepal Rastra Bank act 1995 on April 26, 1956. As the country's central bank, this bank has the sole right to issue currency notes, coins and is responsible to manage the country's foreign exchange reserves. The bank also renders advices to the government on financial and economic matters (Mahat, 1981). The securities which are sold by government to collect the fund are called government securities.

Government sells various securities in the market. Treasury Bills, Development 
Bonds, National Saving Bonds, Special Bonds and Citizen Saving certificates are known as government securities in Nepal. Government securities are issued to raise capital in the market. The main source of internal debt is government bonds. Government takes loan from its own people as well as financial institutions to fulfill the budgetary deficit and others purpose, this type of loan is called internal debt. Government bond is one of the most important issuance of the government to maintain the deficit budgetary system of Nepal. Government bond is a part of public debt (Mahat, 1981). The developing country like Nepal is facing the main challenge of inadequacy of capital for the investment in development activities. Due to this reason government issues various securities in the country. The collected funds are spent on development function for the welfare of people. Government commences various projects in the county. These are not for getting benefit but for the welfare of the people. Therefore, it is believed by all that government works in the country on behalf of people for it has high responsibility to develop country. The government securities play an important role in the economic development of the country. It is very difficult to get uniform definition of government securities. The most important aim of the government securities are to raised the fund to government to fill the gap between the revenue and expenditure. Government bond is regard as the temporary sources of financing for various government functions. Government needs funds to maintain peace and law and order in the country (Lekhi, 1995). The huge amount of funds required by the police and army force is an example of the current situation. Therefore, issue of government bond in such situation is the main source for raising funds internally. Internal debt is the most absolutely essential tool of financial management.

\section{Objective}

The objective of the research paper is to examine the investor's interest and awareness towards government securities in Nepal.

Hypothesis

$H_{1}$ : The attitude of Nepali people is affected by their profession

$\mathrm{H}_{2}$ : The lower income groups are more interested to purchase the government securities.

$H_{3:}$ The people of urban area are more aware towards the government securities than the people of rural area.

$H_{14}$ : The academic background and the awareness are dependent with each other.

\section{Literature Review}

Conceptual Review

Promissory Note

A promissory note is also known as liquid notes because it can be exchange easily and the ownership can be transferred by simply endorsement. It is not necessary to go NRB to transfer the ownership of this note. In other words, the note whose ownership can be transferred by endorsement is known as promissory note. This note can't be transferred particularly. It should be transferred in full amount. In first issue, the promissory note is issued for individual only but the ownership will be transferred to institution by the domestic endorsement, if the ownership will be transferred to institution by the domestic 
endorsement, the promissory note should be changed into stock by giving a notice to NRB.

\section{Stock}

Stock is also known as the secured security because the ownership of this bond can't be transferred by endorsement. To transfer the ownership of stock, the owner of the stock should be registered on application in NRB under dwelling the rule of NRB. The ownership of stock can be transferred with full amount as well as partially, Institution can purchase only the stock as long-term bond but the individual can purchase both promissory note and stock.

Prize bond

Whole or partial amount from the interest amount is given as the prize from lottery system is known a prize bond. Interest is not given in this bond. In this bond, the lottery may be gained before the maturity period of bond and it is only the most attraction of this bond. The principle will be repaid after the certain period. Prize bond was issued by Nepal Government in fiscal year 1967 through NRB.

\section{Bearer Bond}

In this bond, which brings the certificate, he can get the payment. The interest rate is fixed in this bond. The word "bearer "is included in the bond; the certificate holder of bond will have the right to get the payment without any formality.

\section{Treasury Bill}

It is a short-term government security to uphold deficit budgetary system. Normally, treasury bills mature in 91 days while some matures in 184 days and 364 days also. It is issued on the basis of auction, so that any individuals and institutions can invest in treasury bills. The treasury bills have been issuing since 1961 in beginning.

\section{Development Bonds}

The bond that is issued to raise the fund from individual and institution for development purpose of nation for long-term is known as development bonds. It is started to rise in Nepal since fiscal year 1963. It can be used as collateral when taking loans. The holders normally obtained $90 \%$ amount of total value, if he keeps them on collateral. It has also fixed and minimum interest percentage, the interest amount will be paid in semiannual basis. NRB has been issuing these bonds in the market on behalf of the government.

\section{National Saving Bond}

It is long-term government bond normally issued for 5 years maturity period. National saving bond can be purchased by non banking sector only like individuals, organizations etc. If the purchaser is institution, it can be purchased in the form of stock and if the purchaser is an individual, it can be purchased in the form of stock as well as in the form of promissory notes. Generally, development bond and national saving bond 
carries the same nature. It has fixed interest rate and can be transferred from one person to another.

\section{Citizen Saving Certificate}

Citizen saving certificate is also long-term bond. Its maturity period is normally 5 years. The natures are same as other long-term bonds like development bond, national saving bonds etc. Citizen saving certificates cannot be used as collateral. If the holders needs fund immediately, the holder of national saving bond and development bond can be used as collateral to these bonds.

\section{Special Bond}

Special bond is issued for special occasion by indicating for special sector by government. Generally special bond is issued if there will be the scarcity of money on the government account and government has to pay the overdraft interest, commission, cash subsidy etc. Special bond is issued only for institution. The holder of this bond can use it as collateral.

The first public issue of government securities took place in Holland in 1542. To raise the necessary funds, the government of Holland issued various securities, the interest to be funded from excise and property taxes enacted for the purpose. Some of these securities were transferable and therefore suitable for resale, and there developed a limited secondary market. Similarly, the first English government security was issued in 1693. In 694, it chartered the bank of England to buy government securities. Alexander Hamilton issued the first U.S. government securities in 1970. The idea was copied from these countries worldwide (Meir, 1999).

In Nepal, the public debt was first raised in 1961 with the issue of Treasury bill. Thereafter the government has been issuing development bond, special bond, national saving bond and other securities to raise the fund internally (Shrestha, 1981). NRB is the central bank of Nepal, issues various government securities on the behalf of Nepal government after analyzing the liquidity position of market, private investment opportunity, average interest rate in the market, inflation attitude of people toward risk bearing capacity, etc.

The government bond can be defined as the loan taken by government through the issue of securities. The concept of government loan had come into practice after $19^{\text {th }}$ century. In the modern era, the function of government has been increasing day by day (Bista, 1986).

Deficit budgetary system in Nepal is the causes for the issue of government securities. The government prepared a national budget for the first time in 1951 and enforced it and has been suffering deficit since the first budget. The increasing trend of deficit budget has been meet by borrowing from public (Tripathi, 1968).

Borrowing is the major sources of government financing. People have option either 
to invest in government securities or private securities. Government issues risk free securities so almost all of the risk averter investors invest in to government securities rather than private securities. The government can brow more cheaply than individuals because of lesser risk (John \& Ann, 1998).

Tripathi, (2014) has found in his research that education, profession and gender do not affect the derivative investing behavior. However income is found to have a significant role on derivatives. He also added that investors are using these securities for different purposes namely risk management, profit enhancement, speculation and arbitrage.

Vipparthi and Morgam (2012) revealed that the investors' perception is dependent on the demographic profile and assesses that the investors' age, marital status and occupation has direct impact on the investor's choice of investment. The study further revealed that female segment are not fully tapped and even there is low target on higher income people. It reveals that Liquidity, Flexibility, Tax savings, Service Quality and Transparency are the factors which have a higher impact on perception of investors.

In the context of Nepal, the major public expenditure categories com under economic services, social services, defense, administrative and miscellaneous services (Khanal, 1988). Thus public expenditure can be classified into two main categories (1) regular expenditure and (2) Development expenditure.

The government of Canada has been issuing various types of government bonds. They have been issued by different governmental bodies. They issue different types of government bonds. In Canada, investors have different attitude while they are making investment towards government securities due to various government bodies in the country (Wayland, 1978)

\section{Research Methods}

The research has adopted descriptive and analytical research design. The primary data has been collected to examine the investor's interest and awareness toward government securities. The population of the research study is the investors of government securities. The judgmental sampling method has been used to collect the data. The primary data has been collected through structured questionnaires. The questionnaires were distributed to two hundred respondents and among of this only 145 respondents had responded. The Chi-square test of hypothesis has been used to test the interest and awareness of Nepali people on government securities. The Ms-Excel has been used to tabulate and analyze the data.

\section{Results}

The analyst may judge the simple approximation instead of the result of test of goodness of fit, test of independence, and test of homogeneity but unless and until it is proved statistically, it cannot be certified as an authentic accreditation. This study has attempted the sample survey among the security holders and concerned other requiring 
their respective interest, comments, grievances, and awareness on government securities. Among 200 sample size, 145 respondent's views were taken which were scattered at most, among the various categories of people in regards to their income, residence, profession, awareness, etc. There were 16 questionnaires, requested to fill up to test the investors' attitude towards government securities.

Investors' Classification

Investors investing in government securities are classified into two types: Institutional Investors and Individual Investors. Out of the total 145 respondents, 43.21 percent belonged to individual investors' group and 19.5 percent were institutional investors while 27.5 percent felt to both the groups and rest were non-investors.

\section{Subscription of Government Securities}

In response to the question of the types of Government Securities that are highly subscribed in the market, a very high majority of 94 respondents (or $69.33 \%$ ) felt that it was Treasury Bills, $23.9 \%$ responded it to be Development Bonds and rest responded it to be National Saving Bonds. None of the respondents thought that Special Bonds and Citizen Saving Certificate were the types of Government securities that are subscribed in the market.

\section{Time to Know about Government Securities}

In response to the question of time since they have known about Government securities, a majority of 55 percent respondents felt that they knew about the Government securities only a few years before, 19.3 percent respondents felt that they knew about it after the restoration of democracy in 1990, 17.7 percent knew about it recently and 4.7 percent knew about it at the time of the first budget speech in Nepal while 3.3 percent knew at other times.

\section{Source to Know about Government Securities}

When the 145 respondents responded on how they came to know about government securities, 51.63 percentage felt that they came to know about government securities through papers and government notices, 23.52 percentages knew from friends, 15.3 percentage knew as they were staff of banks, 6.67 percentage came to know from government notices and employees circle as they themselves were government employees, and the rest 2.88 came to know through other media, like teachers, books, etc.

\section{Condition to Induce on Government Securities}

In response to the question of the conditions that induce the investors to invest in Government Securities, 59.1 percent respondent that tax-free and collateral securities induce the investors in invest in government securities. 26.14 percent respondents were of the opinion that only tax-free conditions would be enough for the inductions, while 7.38 percent thought only collateral conditions would perform the task. The rest 7.38 respondents thought there are other conditions that induce the investors to investment. 


\section{Reason for Investment in Government Securities}

In response to the question of the reason for the investment in government securities, 81.54 percent respondents responded that investment in government securities was riskless. 5.42 percent thought the zero liquidity risk was the reason while the other 4.31 percent thought that the declining interest rate in other investment sectors (i.e. the interest rate on saving account) was the reason. A minority of 1.87 percent respondents thought that the lack of other corporate securities was lending to the investment in government securities. Only 6.86 percent people responded that they had not idea.

\section{Possibility of Default Rise in Government Securities}

The respondents about the possibility of default risk on the investment on Government Securities in terms of annual interest payment and principal at maturity. 64.8 percent felt there was no risk and 29.5 percent responded that there was some risk while only 3.4 percent reported that there was a high risk 2.3 percent person had no idea.

\section{Risk on Interest and Principal at Maturity}

The feeling of security about the investment in Government Securities is very important. All the respondents responded about how secured they felt about their investment in the Government Securities. They study showed that most of the investors were very much secured about such an investment as 81.25 percent respondents reported that they were $100 \%$ secured to get the interest and principal. 11.4 percent reported that they were $100 \%$ secured to get the principal only and only 7.4 percent felt unsecured.

\section{Security of Interest and Principal}

Collecting interest and principal of the investment should be an easy process. All the respondents responded about the difficulties in collecting interest and principal of the investment. A majority of 55.7 percent respondents reported that it was difficult due to the behavior of the officials, 26.14 percent reported that there was no difficulty.

\section{Reason to sell the Government Securities}

The respondents reported about the reasons that make them sell the Government Securities. A majority of the respondents (62.48\%) said that they sell the Government Securities to grab alternative investment opportunity (i.e. to invest on shares issued by the reputed private companies), 15.1 percent respondents said they sold them to benefit from investment in real asset (tangible assets). 13.36 percent respondents reported that they sold the Government securities to meet their household requirements and rest (13 respondents) sold them when the stock is overprices.

\section{Uncertainty on Investment in Government Securities}

In response to the question about when the respondents felt uncertain about investment on Government Securities, a majority of 44.32 respondents reported that the lack of consideration of time value of money made them fell uncertain and 26.14 percent felt that the complex rules and regulations to be followed a the time of making. 


\section{Buyers on Government Securities}

Out of the total 145 respondents, 48 (33.25 percent) reported that the buyers of securities were financial institutions, 39(26.7 percent) responded they were service holders, 32 (21.86 percent) felt they were business firms, 24 (16.48 percent) responded them to be retired people and the rest 2 ( 1.7 percent) had no idea.

\section{Source of Income to Invest in government Securities}

The respondents responded about the income source they used to purchase the Government Securities. A large 69.9 percent respondent reported that they used idle cash, 12.5 percent used residual amount, 7.4 percent used profit from business, 5.7 percent used sale of fixed assets and the remaining 4.5 percent took loan in order to purchase the Government Securities.

\section{Subscription of Government Securities}

There are some good reasons for the full subscription of Government Securities: the good marketing policy of NRB, the influence from intimate partners, good investment sector from risk and return perspective, and the lack of information of other investment sector. The respondents were questioned about the order of priority of these reasons. Though there was a lot of variation in setting the priority of the reasons, most of the respondents set a greater priority to the lack of information of order investment sector.

\section{Use of Government Borrowing}

The Government of Nepal has been collecting huge amount of money from people. The respondents answered about their opinion about the productive use of the collected amount $62(42.64 \%)$ respondents were of the opinion that the collected money was productively used. It was found that most of the respondents were service holders. $36(24.84 \%)$ respondents reported that amount had been unproductively used and 33 (22.86\%) thought that it misused. It was found that most of these respondents were students who thought that the money collected was either misused or unproductively used. the remaining $14(9.66 \%)$ reported that they do not have any idea in matter. Rather they were of the opinion that the collected money had used in some productive sector.

\section{Test of Hypothesis}

Non parametric test i.e. chi-square $\left(x^{2}\right)$ is used to find out the interest and awareness of Nepali people towards the government securities. Four tests have been done based on the various categories of the sample i.e. educational background, profession, residence, annual income education etc. Basically, the tests are adopted by thinking that the samples can represent the attitude of Nepali people towards the government securities. 
Table 1

Hypothesis Test for Investor Attitude on Government Securities in Terms of their Occupation

\begin{tabular}{lcccc}
\hline \multicolumn{1}{c}{ Attitude } & $\begin{array}{c}\text { Occupation } \\
\text { Businessman }\end{array}$ & $\begin{array}{c}\text { Civil Servant \& } \\
\text { Permanent Employees } \\
\text { of Organization }\end{array}$ & $\begin{array}{c}\text { Students, Retired } \\
\text { Person and Others }\end{array}$ & Total \\
\hline More Interested & 15 & 48 & 9 & 72 \\
Less Interested & 35 & 22 & 16 & 73 \\
\hline Total & $\mathbf{5 0}$ & $\mathbf{7 0}$ & $\mathbf{2 5}$ & $\mathbf{1 4 5}$ \\
\hline
\end{tabular}

Source: Field Survey (2018)

It is assumed that the people may have different attitude towards the government securities i.e. they may be more interested, less interested more aware, less aware to government securities. It is also assumed that their education, profession, educational background, residence and their annual income affect these attitudes. Here, these attitudes and the effect of various categories are tested by adopting the chi-square $\left(\mathrm{x}^{2}\right)$ test of hypothesis at 5 percent significant level.

Table 2

Calculation of Chi-Square $\left(x^{2}\right)$

\begin{tabular}{ccccc}
$\begin{array}{c}\text { Observed } \\
\text { Frequency (O) }\end{array}$ & $\begin{array}{c}\text { Expected } \\
\text { Frequency (E) }\end{array}$ & $\begin{array}{c}(\mathrm{O}-\mathrm{E}) \\
(\mathrm{O}-\mathrm{E})^{2}\end{array}$ & $\begin{array}{c}(\mathrm{O}-\mathrm{E})^{2} \\
\mathrm{E}\end{array}$ \\
\hline 15 & 24.83 & -9.83 & 96.63 & 3.89 \\
35 & 25.17 & 9.83 & 96.63 & 3.84 \\
48 & 34.76 & 13.24 & 175.30 & 5.04 \\
22 & 35.24 & -13.24 & 175.30 & 4.97 \\
9 & 12.41 & -3.41 & 11.63 & 0.94 \\
16 & $12 . .59$ & 3.41 & 11.63 & 0.92 \\
\hline Total & & & & 19.6 \\
\hline
\end{tabular}

Since the calculated value of Chi-Square is higher than the tabulated value of Chisquare at $5 \%$ level of significance for 2 degree of freedom. So, Null hypothesis is rejected, which means that the attitude of Investor's are affected by their occupation i.e., the businessman, student and retired person are less interested to purchase the government securities, because, they have enough time to seek the profitable stock and they can take the opportunity of the market. But the civil servant and the permanent employees of organized bodies haven't enough time. So they are more interested to purchase the government securities. 
Table 3

Hypothesis Test for Investor Attitude on Government Securities in Terms of their Income Level

\begin{tabular}{lcccc}
\hline \multicolumn{1}{c}{ Attitude } & $\begin{array}{c}\text { Investors With Annual Income } \\
\text { Equal to Rs } \\
\mathbf{5 0 , 0 0 0}\end{array}$ & $\begin{array}{c}\text { More than Rs. } \mathbf{5 0 , 0 0 0} \\
\text { but less than Rs. } \\
\mathbf{3 , 0 0 , 0 0 0}\end{array}$ & $\begin{array}{c}\text { More than or Equal } \\
\text { to Rs. } \mathbf{3 , 0 0 , 0 0 0}\end{array}$ & Total \\
\hline More Interested & 33 & 53 & 7 & 93 \\
Less Interested & 12 & 27 & 13 & 52 \\
\hline Total & $\mathbf{4 5}$ & $\mathbf{8 0}$ & $\mathbf{2 0}$ & $\mathbf{1 4 5}$ \\
\hline
\end{tabular}

Source: Field Survey (2018)

Table 4

Calculation of Chi-square $\left(x^{2}\right)$

\begin{tabular}{ccccc}
\hline $\begin{array}{c}\text { Observed } \\
\text { Frequency (O) }\end{array}$ & $\begin{array}{c}\text { Expected } \\
\text { Frequency (E) }\end{array}$ & $(\mathrm{O}-\mathrm{E})$ & $(\mathrm{O}-\mathrm{E})^{2}$ & $\begin{array}{c}(\mathbf{O}-\mathrm{E})^{2} \\
\mathbf{E}\end{array}$ \\
\hline 33 & 28.86 & 4.14 & 17.14 & 0.59 \\
12 & 16.14 & -4.14 & 17.14 & 1.06 \\
53 & 51.31 & 1.69 & 2.86 & 0.06 \\
27 & 28.69 & -1.69 & 2.86 & 0.10 \\
7 & 12.83 & -5.83 & 33.99 & 2.65 \\
13 & 7.17 & 5.83 & 33.99 & 4.47 \\
\hline Total & & & & 8.86 \\
\hline
\end{tabular}

Source: Field Survey (2018)

Since the calculated value of Chi-square is higher than the tabulated value of Chisquare at $5 \%$ level of significance for 2 degree of freedom. So, Null hypothesis is rejected in this level. i.e.; Alternative hypothesis is accepted, which means that the Lower income groups are more interested to purchase the government securities.

Table 5

Hypothesis Test for Investor Attitude on Government Securities on the basis of Geographical Area

\begin{tabular}{|c|c|c|c|}
\hline \multirow{2}{*}{ Attitude } & \multicolumn{2}{|c|}{ Investors } & \multirow[t]{2}{*}{ Total } \\
\hline & Rural Area & Urban Area & \\
\hline More Aware & 33 & 65 & 93 \\
\hline Less Aware & 30 & 17 & 47 \\
\hline Total & 63 & 82 & 145 \\
\hline
\end{tabular}

Source: Field Survey (2018) 
Table 6

Calculation of Chi-square $\left(x^{2}\right)$

\begin{tabular}{ccccc}
\hline $\begin{array}{c}\text { Observed } \\
\text { Frequency (O) }\end{array}$ & $\begin{array}{c}\text { Expected } \\
\text { Frequency (E) }\end{array}$ & $(0-E)$ & $(0-E)^{2}$ & $\frac{(0-E)^{2}}{E}$ \\
\hline 33 & 42.58 & -9.58 & 91.78 & 2.16 \\
30 & 20.42 & 9.58 & 91.78 & 4.49 \\
65 & 55.42 & 9.58 & 91.78 & 1.66 \\
17 & 26.58 & -9.58 & 91.78 & 3.45 \\
\hline Total & & & & 11.76 \\
\hline
\end{tabular}

Since the calculated value of Chi-square is higher than the tabulated value of Chisquare at $5 \%$ level of significance for 1 degree of freedom. So, Null hypothesis is rejected in this level. i.e.; Alternative hypothesis is accepted, which means that the people of urban area are more aware towards the government securities than the people of rural area.

Table 7

Hypothesis Test for Investor Attitude on Government Securities in Terms of their Academic Backgrounds

\begin{tabular}{lccc}
\hline Attitude & $\begin{array}{c}\text { Academic Background } \\
\text { With Economics, Finance, } \\
\text { Management \& Commerce }\end{array}$ & Others & Total \\
\hline More Aware & 80 & 28 & 108 \\
Less Aware & 14 & 23 & 37 \\
\hline Total & $\mathbf{9 4}$ & $\mathbf{5 1}$ & $\mathbf{1 4 5}$ \\
\hline
\end{tabular}

Source: Field Survey (2018)

Table 8

Calculation of Chi-square $\left(x^{2}\right)$

\begin{tabular}{ccccc}
\hline $\begin{array}{c}\text { Observed } \\
\text { Frequency (O) }\end{array}$ & $\begin{array}{c}\text { Expected } \\
\text { Frequency (E) }\end{array}$ & $(0-E)$ & $(0-E)^{2}$ & $\frac{(0-E)^{2}}{E}$ \\
\hline 80 & 70.01 & 9.99 & 99.80 & 1.43 \\
14 & 23.99 & -9.99 & 99.80 & 4.16 \\
28 & 37.99 & -9.99 & 99.80 & 2.63 \\
23 & 13.01 & 9.99 & 99.80 & 7.67 \\
\hline Total & & & & 15.89 \\
\hline
\end{tabular}


Since the calculated value of Chi-square is higher than the tabulated value of Chisquare at $5 \%$ level of significance for 1 degree of freedom. So, Null hypothesis is rejected in this level. i.e.; Alternative hypothesis is accepted, which means that the academic background and the awareness are dependent each other's i.e.; the people whose academic background is Economics, Finance, Management \& Commerce are more aware towards the government securities than the people of others background.

\section{Conclusion}

The study shows that Nepali investors are attracted to government securities in comparison to other investment sectors. Most of investors in Nepal are risk averter and they search less risky investment. Different people are participating in government securities such as, rich, poor, educated, uneducated, etc. This has supported general assumption that only required persons, civil servants are interested in government securities. In response to collect sample, some investors responded some sorts of complaints and grievances against the marketability of security and its low interest rate than private investments. Government can rise from internally and externally.

\section{References}

Bista, B.G. (1986). Government Finance in Nepal.Laligurans Prakashan, Kathmandu: Nepal

John, F. D and Ann F. F, (1998). Government Finance. Illinioois-63430: Richard D. Irwin, Inc. Homework

Khanal, D.R. (1988). Public Expenditure in Nepal. Green Park Extention, New Delhi: Streling Publisher Pvt. Ltd.

Mahat, R.S. (1981). Capital market, financial flows and industrial finance in Nepal. Lalitpur: Sajha Prakashan,Pulchok, Nepal

Meir, K. (1999). Financial Institution and Market. New Delhi: TATA McGraw Hill Publishing Co. Ltd.

Shrestha, B.P. (1981). A Introduction to Nepali Economy. Kathmandu: Ratna Pustak Bhandar, Nepal

Tripathi, G. (2014). An Empirical Investigation of Investors Perception towards Derivative Trading, Global Journal of Finance and Management, 2014, Vol. 6, No. 2, pp. 99-104, ISSN 0975-6477.

Tripathi, R.N. (1968). Public finance in under developing countries. The World Press (Pvt.) Ltd.

Vipparthi, M.\& Morgam, A. (2012). Perceptions of Investors on Mutual Funds - A comparative study on Public and Private sector mutual funds, Tecnia Journal of Management Studies, Vol. 7, No. 1, April - September 2012.

Wayland, D. G. (1978). Government finance national, state and local. New Gersuy: Prentice Hall, Inc.Engle W. Cliffs 